\section{READERS' COMMENTS}

\section{Dr. Thomas N. James, MD, MACP (1925-2010): In Memoriam}

This brief note is written to laud the memory of Dr. Thomas N. James, MD, MACP (Figure 1), author and member of the editorial board of The American Journal of Cardiology and other outstanding international journals. ${ }^{1}$ Dr. James, an internationally renowned cardiologist and pathologist, scientific investigator, and professor, whose focus was on cardiovascular pathology, especially of the cardiac conduction system, died September 11, 2010, at the age of 84 years.

Dr. James gained international recognition in 1961 with the publication of a textbook on the anatomy of the coronary arteries. $^{2}$ In the years that followed, Dr. James's interest turned to the conduction system of the heart. His many publications in this area traced the electrical pathways, two of which are named for him (the James fibers, one physiologic internodal and one pathologic atriofascicular), and led to refinements in cardiac pacemaker and cardiac electrical design. ${ }^{1-3}$ Of particular interest, the conduction fibers that originate in the atrial internodal tracts and pass to the ventriculum but bypass the atrioventricular node are called James accessory fibers. These discoveries brought Dr. James to international prominence.

In 1979, he was elected president of the American Heart Association; in 1982, he became president of the International Society and Federation of Cardiology; and in 1986, he presided over the 10th World Congress of Cardiology. From 1988 to 1998 , he served as director of the Cardiovascular Center of the World Health Organization. ${ }^{1}$

In the more than 40 years since Dr. James's original studies on the histopathology of the cardiac conduction system, an ever expanding "carousel" of well-documented scientific explorations enriching the published research on anatomic-histologic, clinical, electrocardiographic, and genetic research of sudden death have been published.

The pioneering research Dr. James produced on long-QT syndrome has had influence well beyond the scientific world and has affected the opinions of sports medicine physicians and primary care physicians, as well as the minds of the public. ${ }^{4}$ The worldwide interest has led to a blooming of anatomic-pathologic, genetic, and clinical scientific research on sudden cardiac death and its underlying high-risk conditions.

More recently, Dr. James wrote the introduction to a monograph on histopathologic research of crib death, ${ }^{5}$ resulting in renewed interest in anatomic-clinical and cardiologic research in this field.

In the experimental field, genetic research into sudden cardiac death and long-QT syndrome has also produced good results, as can be seen in the most recent issue of Nature. ${ }^{6}$ The ongoing research on genetic alterations of the long-QT syndrome, although only recently published, is nonetheless encouraging.

I had the blessing of working with Dr. James for more than a year, and I could see his integrity, intelligence, strong

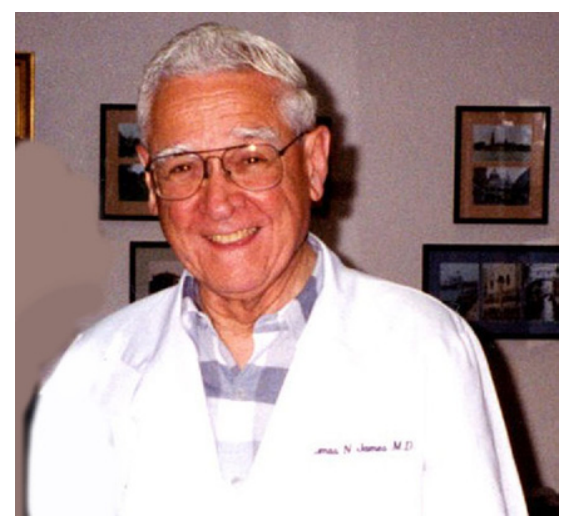

Figure 1. A recent photograph of Dr. Thomas N. James.

morals, and perseverance. We all-students, trainees, colleagues, researchers, readers, and patients-will remember him. Beyond his legacy as a much appreciated teacher and president of the University of Texas Medical Branch at Galveston, we remember him above all for his pioneering and enduring contributions in research.

Dr. James remains with us, as his research on the conduction system, the "heart of the heart," is beating vividly and is a stimulus for the growing pursuit of cardiologic, anatomic-pathologic, and genetic research into the sudden death of human beings in all age groups.

Giulia Ottaviani, MD

Milan, Italy 30 March 2011

1. Thomas N. James, M.D., M.A.C.P. Available at: http://www.tnjames.com/index.html. Accessed on March 30, 2011.

2. James TN. Anatomy of the Coronary Arteries. Hagerstown, Maryland: Harper Brothers, 1961.

3. James TN. The internodal pathways of the human heart. Prog Cardiovasc Dis 2001;43:495-535.

4. James TN, Froggatt P, Atkinson WJ Jr, Lurie PR, McNamara DG, Miller WW, Schloss GT, Carroll JF, North RL. De subitaneis mortibus XXX. Observations on the pathophysiology of the QT syndromes with special reference to the neuropathology of the heart. Circulation 1978; 57:1221-1231.

5. Ottaviani G. Crib Death. Sudden Unexplained Death of Infants: The Pathologist's Viewpoint. Berlin, Germany: Springer-Verlag, 2007.

6. Itzhaki I, Maizels L, Huber I, Zwi-Dantsis L, Caspi O, Winterstern A, Feldman O, Gepstein A, Arbel G, Hammerman H, Boulos M, Gepstein L. Modelling the long QT syndrome with induced pluripotent stem cells. Nature 2011;471:225-229.

doi:10.1016/j.amjcard.2011.04.001

\section{Asymmetry in Funnel Plot}

I read with great interest the meta-analysis by Parise et $\mathrm{al}^{1}$ comparing intravascular ultrasound-guided and angiography-guided percutaneous coronary intervention. The investigators concluded in the text of the abstract that intravascular ultrasound "guidance for bare metal stent implantation improved the acute procedural results (angiographic minimum lumen diameter) and thereby reduced 